Received 27.02.2018

Reviewed $\quad 09.04 .2018$

Accepted 08.05.2018

A - study design

B - data collection

C - statistical analysis

D - data interpretation

$\mathbf{E}$ - manuscript preparation

F - literature search

\section{Perspectives on offshore wind farms development in chosen countries of European Union}

\author{
Leszek DAWID ${ }^{\mathrm{ABCDEF} \bowtie}$
}

Technical University of Koszalin, Faculty of Civil Engineering, Environmental and Geodetic Sciences, ul. Śniadeckich 2, 75-453 Koszalin, Poland; e-mail: leszek.dawid@tu.koszalin.pl

For citation: Dawid L. 2018. Perspectives on offshore wind farms development in chosen countries of European Union. Journal of Water and Land Development. No. 38 p. 27-34. DOI: 10.2478/jwld-2018-0039.

\begin{abstract}
At the end of 2016 there were 84 wind farms under construction in 11 European countries. Investments in this sector are enormous. The average cost of a wind farm construction amounts to approx. 4 mln EUR per $1 \mathrm{MW}$ of installed power. Offshore wind energy production also plays a significant role in the process of ensuring energy security in Europe, and in reduction of greenhouse gases. The objective of this paper is to present prospects of offshore wind energy farms development in the leading member states of the European Union as regards this problem. In this paper offshore wind farms in Germany and Denmark have been studied. In the paper the power of wind farms, the support systems as well as criteria related to location of wind farm offshore have been analysed. German and Danish sectors of offshore wind energy are strongly supported by respective governments. Both countries aim at yearly increase of wind energy share in total energy production. The research has been conducted based on the analysis of acts, regulations, the subject's literature and information from websites.
\end{abstract}

Key words: offshore wind farms, renewable energy sources, support systems, wind energy

\section{INTRODUCTION}

Renewable energy plays an increasingly important role in an energy system of many countries [MiKOlAJCZAK et al. 2009; TRANCIK 2014]. The European Union is the leader in the area of offshore wind energy and each year is marked with a remarkable development of this sector. The winds blowing from over the sea are stronger and steadier than those over the land. Thanks to this wind farms supply more power per an area unit than land wind farms [BWE 2017]. Turbines can be of a larger size, are easier to transport to the installation site, do not raise in the society such negative emotions as is the case with wind farms on the land [DAWID 2017a, b; OdnawialneFirmy 2018; STRYJECKI et al. 2011]. Scope of legislative powers coastal countries possess over the sea is regulated by the United Nations Convention on the Law of the Sea from the year 1982 [United Nations Convention... 1982], which differentiates between several sea zones. In the case of offshore wind power production the most important ones are the territorial waters and exclusive economic zone (EEZ). Within their territorial waters coastal countries enjoy full sovereignty and hence possess legislative powers same as on the land. The market of offshore wind farms has been growing rapidly. At the end of 2016 there were 84 wind farms under construction in 11 European countries. An increasing interest in this market is demonstrated by oil and gas companies. Investments by Shell in Holland or Statoil energy production company in Great Britain are an example of this interest [PWC 2018]. Moreover, Statoil is the primary investor of the first commercial floating wind farm in Scotland. It consists of floating wind power generation plants which are not permanently attached to the sea bottom. The name of the wind farm is Hywind, it consists of 5 turbines of the power of $6 \mathrm{MW}$ each. This turbine installation allows locating wind farm at bigger depths at which placing turbines 
built on traditional foundation would not be profitable [Gramwzielone.pl 2017c].

Investments in this sector are huge. An average cost of a wind farm construction amounts to approx. $4 \mathrm{mln}$ EUR per $1 \mathrm{MW}$ of installed power. Investment expenditure as regards financing development of wind farms totalled 27.5 billion EUR in 2016. In addition, offshore wind power production plays a significant role in the process of ensuring energy security in Europe since as regards generated energy wind has contributed to the production of approx. $300 \mathrm{TWh}$ of electric power, which has satisfied $10.4 \%$ of the European electric power demand [PSEW 2016]. According to WindEurope [2017], in the years 2017-2030 investment in the European wind sector are to reach approx. 239 billion EUR, which means that in the year 2020 the potential of European wind power production will have grown up to around $204 \mathrm{GW}$. By this time wind will have become the largest renewable source of energy in Europe as regards installed power, satisfying approx. $16.5 \%$ of the energy demand on our continent [BiznesAlert 2017]. Besides, the association further assumes that in the longer time perspective, by 2030, the share of wind in the European energy mix will have increased up to $30 \%$. Investments in offshore wind farms could also to a large degree support reduction of greenhouse gases and thus support implementation of the European Union (EU) policy in this respect [Directive 2001/77/EC; Directive 2003/30/EC; Directive 2009/28/EC].

The objective of the paper is to present prospects of offshore wind energy farms development in the leading member states of the EU (Fig. 1). In this paper offshore wind farms in Germany and Denmark have been studies. In the paper the power of wind farms, the support systems offered by specific countries as well as criteria related to location of wind farm offshore have been analysed. This problem will be the topic of a series of papers. In subsequent articles wind farms situated in Great Britain, Netherlands, Belgium and other will be analysed.

\section{MATERIALS}

The research has been conducted based on the analysis of acts, regulations, the subject's literature and information from websites. The techniques of qualitative analysis of documents and descriptive analysis have been. The basis for the selection of the analysis method has been the type of gathered information.

\section{RESULTS AND DISCUSSION}

\section{OFFSHORE WIND FARMS IN SELECTED EU MEMBER STATES}

In 2017 in Europe offshore wind power production reached the record high level of 3,148 MW of new installed power. This corresponds to 560 newly installed offshore wind turbines on 17 wind farms
[WindEurope 2018a]. In 2017 the final investment decision (FID) for 6 new projects of offshore wind farms were published, which are to be installed in the following years. New investments will total 7.5 bn EUR and will supply $2.5 \mathrm{GW}$ of energy power [WindEurope 2018a]. At the end of 2016, 97\% of the total power of all offshore wind farms in Europe was installed in five EU member states. Great Britain has the largest potential of offshore wind in Europe accounting for $40.8 \%$ of all installations; next there is Germany (32.5\%), Denmark (10.1\%), Netherlands (8.8\%) and Belgium (5.6\%) [WindEurope 2018a], which is illustrated by Figure 1. The years 2015 and 2016 were the record years for offshore wind power production in Europe. In 2015 over $3.5 \mathrm{GW}$ of new power was installed and connected to the grid. This was mainly the result of putting into use a wind farm in Germany - approx. 2.4 GW and in Great Britain approx. $1 \mathrm{GW}$ [PWC 2018]. In 2016 in the EU the total of $12.5 \mathrm{GW}$ of new power of wind power generation plants was installed and connected to the grid. 10,923 MW was installed on the land while 1,558 MW was installed offshore [GWEC 2016]. At the end of 2016 Great Britain had the biggest power of offshore wind farms equalling more than $5.2 \mathrm{GW}$, which is shown in Figure 1. The countries next in line are Germany with the production of approx. 4.1 GW, China (approx. 1.6 GW), Denmark (approx. 1.3 GW), Netherlands (approx. 1.1 GW), Belgium (approx. 0.7 GW).

\section{DENMARK}

In 1991 in Vindeby, Denmark, the first in history commercial offshore wind farm was built, which initiated the development of offshore wind energy production. At the end of 2016 the power of installed offshore wind farms totalled around 1,300 MW (Fig. 2). In 2015 Denmark set a world's record of using renewable energy. As it is shown in the government information Energinet.dk, in 2015 over $40 \%$ of the consumed energy in Denmark came from wind [DRUŚ 2016]. Danish ambition is 50\% of the electric power demand derived from wind in 2020 [GWEC 2016]. In 2016 the projects of two wind farms located in the Baltic Sea and in the North Sea were approved. The tender was won by Swedish energy company Vattenfall. It has informed about the beginning of construction of Horns Rev 3 offshore wind farm, whose power will reach $406 \mathrm{MW}$. This investment is the effect of the won tender conducted by the Danish government. ${ }^{2}$ Horns Rev 3 wind farm will consist of 49 wind power generation plants, whose power will be $8.3 \mathrm{MW}$ each. The wind power generation plants are to be built in the North Sea within the area of 88 $\mathrm{km}^{2}$. The expected date of completion of construction is 2018 [Gramwzielone.pl 2017a]. Kiegers Flak offshore wind farm with the power of $600 \mathrm{MW}$ is to be built in the Baltic Sea. It will consist of 72 wind power generation plants, whose power will be $8 \mathrm{MW}$ each. It will be situated within the area of $183 \mathrm{~km}^{2}$. 


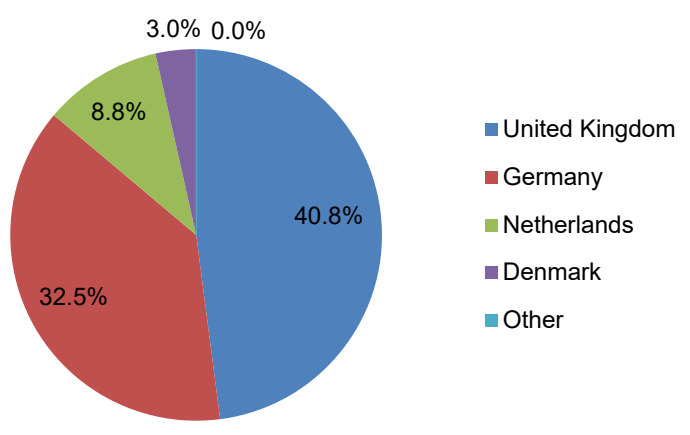

Fig. 1. Power of offshore wind farms in $\%$ at the end of 2016 in Europe; source: own elaboration on the basis of WindEurope [2017]

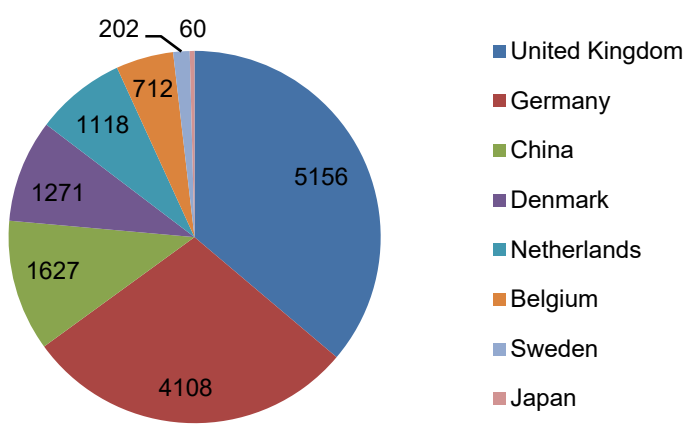

Fig. 2. Power of offshore wind farms in MW at the end of 2016 in selected countries; source: own elaboration on the basis of GWEC [2016]

The expected date of commissioning is 2021 [4C Offshore 2018a]. Additionally, in the Baltic Sea, near the shoreline, Vesterhav Syd and Vesterhav Nord wind farms of the total power of 350 MW will be constructed. It will consist of 41 wind power generation plants, whose power will be $8 \mathrm{MW}$ each. These wind power generation plants will be built within the area of $105 \mathrm{~km}^{2}$. The expected date of commissioning is 2020 [4C Offshore 2018b]. Close to the Denmark's coast within the area of $5 \mathrm{~km}^{2}$ a small wind farm of the power of $28 \mathrm{MW}$ called Nissum Bredning Vind will be built. It will consist of 4 wind power generation plants, whose power will be $7 \mathrm{MW}$ each. In Nissum Bredning Vind wind farm one of the largest wind turbines in the world by Siemens will be used. Apart from new turbines, in this project Siemens will use new technologies as regards wiring as well as foundation. The cost will be approx. 40 mln EUR. The expected date of commissioning is 2018 [BiznesAlert 2018b]. Denmark has plans to install almost 1,400 MW of offshore wind power by the year 2021. This means doubling the current energy production capacity by offshore wind farms. Denmark's power capacity of land and offshore wind farms is shown in Figure 3. From 1995 until 2016 the total increase of offshore wind farms power amounted to 2,651 MW (Fig. 4).

Conditions governing permits for location of offshore wind farms are specified in the 27 December 2008 Promotion of Renewable Energy Act [Promotion... 2008]. It has been in force and effect since

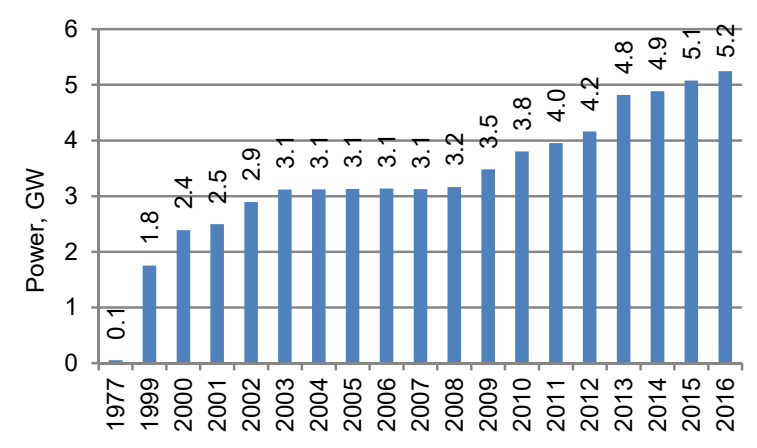

Fig. 3. Power capacity of land and offshore wind farms in Denmark in the years 1995-2016 in GW; source: Danish Energy Agency [2018]

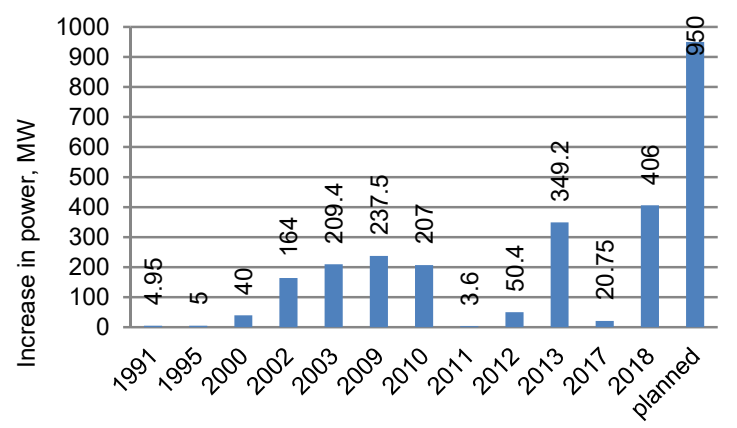

Fig. 4. Increase of offshore wind farm power in Denmark in the years 1991-2017, under construction in 2018 and planned by 2021 in MW; source: own elaboration based on data of Danish Energy Agency [2018], PWC [2018]

1 January 2009. Pursuant to the act Minister of Climate and Energy establishes "green system" from which subsidies for municipalities that have undertaken activities increasing acceptance of wind turbines installation are paid out. The subsidies are granted in the amount of $0.004 \mathrm{DKK}$ for $\mathrm{kWh}$, for 22,000 hours of peak load for each wind turbine. The act also requires all municipalities to prepare and adopt a supplement to their municipal plans with areas reserved for wind turbines. Moreover, the act promotes the development of small electric power plants, using renewable energy and connected to the grid, by means of a special fund. The fund amount to $25 \mathrm{~m}$ DKK per year for four years. New grids are to be managed by transmission networks operator Energinet.dk. The act also requires individuals installing one or more wind turbines to offer at least $20 \%$ of share capital up for sale. A sale offer has to be directed to residents living $4.5 \mathrm{~km}$ or less from the nearest turbine. Local residents can purchase shares of installed wind turbines. Furthermore, the act regulates scrapping programme of old turbines. A certificate of scrapping can be obtained by replacing old wind turbines with new, more efficient ones. This entitled to an additional bonus for $1 \mathrm{kWh}$ of produced energy.

In Chapter 3 of the act [Promotion ... 2008] it is stated that the right to exploit energy from water and wind in the territorial waters and exclusive economic zone (up to 200 nautical miles) around Denmark belongs to Denmark. Thus a developer intending to 
build offshore wind farms has to obtain a permit from the Danish government. It is granted in the form of a license. It can be obtained in two ways. The first way is by means of a governmental public procurement conducted by Danish Energy Agency, the second one by means of the so-called open door procedure. In a governmental public procurement, Danish Energy Agency calls for tenders for an offshore wind farm project of a specific size within precisely identified geographic area. In the procedure of open door a project developer undertakes to construct an offshore wind farm of a chosen size within a specific area. A project developer has to file for an application to carry out preliminary research in a given area. An application must include a project description, expected scope of preliminary research, size and number of turbines as well as geographical location of the project. In the open door procedure an investor pays for a grid connection. If the results of preliminary research initiated by Danish Energy Agency indicate that a proposed project can be approved, the project developer can obtain a license for project development. In both procedures, an applicant must obtain three licenses:

a) a license for conduction preliminary research,

b) a license for construction of wind turbines (provided that preliminary research indicates that a project is appropriate and does not collides with other offshore wind farm),

c) a license for exploitation of wind energy by a specific number of years and approval of quantity of electric power production [PWC 2018].

The three licenses are issued in successively for a given project. After these three licenses have been obtained an environmental impact assessment (EIA) of wind farms is needed. Until the present it was necessary to carry out such an assessment for all existing Danish offshore wind farms. A detailed procedure is set out in Executive Order no. 68 of 26th January 2012 [Danish Energy Agency 2012]. Danish Energy Agency has additionally worked out guidelines regarding EIA for offshore wind farms. These guidelines refer to problems related with environment protection at sea only. The majority of new offshore wind farms in Denmark are built after a tender procedure has been conducted. Danish Energy Agency expects an applicant to provide a price per $\mathrm{kWh}$ in the form of a full price for which bidders are ready to produce a specific quantity of electric power. A wind farm owner will have to sell electric power on the market and obtain a subsidy in order to cover the difference between a market price and the offered one. A developer which offers production of energy at the lowest price wins. Energy production price depends on numerous factors. It is influenced by a project location, wind conditions, sea depth, distance from the shore or a market situation in a given period. All tenders in Denmark are decided by political agreements regarding energy. Electric power generated by wind farms as the procedure of open door is granted a price bonus at the same rate as land wind turbines. The bonus amounts to $25 \mathrm{DKK} \cdot \mathrm{kWh}^{-1}$ above the market price. If the market price added to a subsidy exceeds 58 $\mathrm{DKK} \cdot \mathrm{kWh}^{-1}$, such a subsidy is reduced appropriately. In the "open door" license application system the state grants a bank guarantee to developers; however, only if they are different than groups of local residents. In the tender system, the subsidy period is normally 20 years. It corresponds to 50 thousand production hours. In the "open door" system the formula of 6.6 thousand hours of full load plus 5.6 MWh per square metre of a wing surface applies. The usual depreciation rate applicable to wind farms is at $25 \%$. Special rules apple to wind farms built after 2013 of power exceeding $1 \mathrm{MW}$. They can be depreciated at $15 \%$. In tenders for construction of offshore wind farms the Danish transmission networks operator Energinet.dk builds and maintains both a transformer station as well as an underwater cable which transmits electric power on the shore from a near-shore wind farm [PWC 2018]. Energinet.dk is responsible for electric infrastructure in Denmark and acts in the capacity of an independent operator of transmission networks system. They can also grant bank guarantees for associations, owners of wind farms or other local groups fulfilling specific conditions as regards loan taken out for financing wind farms. These can be location research, technical, studies connected with farm construction costs as well as preparation of applications, in order to install one or more wind turbines.

\section{GERMANY}

The very first offshore wind farm in Germany Alfa Ventus - began its operation in April 2010. It was a pilot project for EWE, E.ON and Vattenfall energy companies [BMWi 2015]. The combined power of land and offshore wind farms in Germany totalled at approx. $49.6 \mathrm{GW}$ at the end of 2016 (Fig. 5) and had generated around $80 \mathrm{TWh}$ of electric power. This makes Germany the third largest market in the world. In 2016 wind farms produced electric power sufficient to meet $15 \%$ of this country's overall demand for electric power [GWEC 2016]. Every year in Germany new wind farms are installed and connected to the grid, which is illustrated by Figure 6. In 2016 Germany was the biggest market in EU for installation of new generating power $-5,443 \mathrm{MW}$, which accounted for approx. $44 \%$ of all EU new installations. $818 \mathrm{NM}$ of new power were installed offshore by Germany in 2016 [GWEC 2016]. In December 2017 another wind farm called Nordsee One became operational (offshore). Its construction cost amounted to approx. 1.2 billion EUR. The installed power is 332 MW. Nordsee One wind farm consists of 54 wind power production plants, whose power is $6.2 \mathrm{MW}$ each. The wind power production plants were built in the North Sea within the area of $35 \mathrm{~km}^{2}$. The dominant investor in the project is Northland Power developer (85\%), the remaining shares are owned by Innogy, a German energy company. 


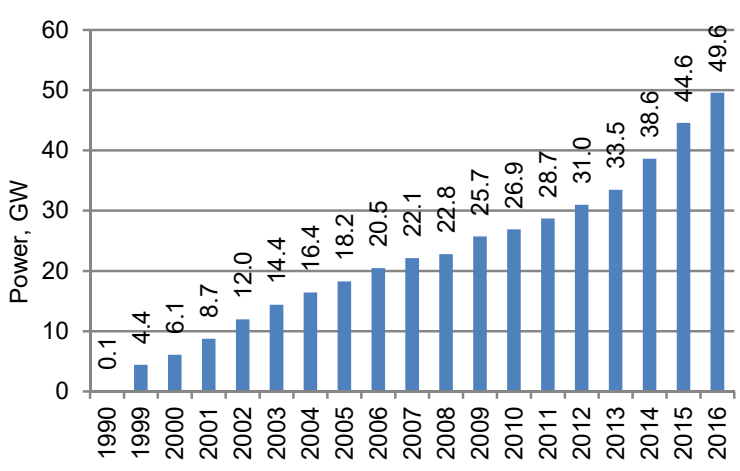

Fig. 5. Power capacity of wind farms in Germany in the years 1990-2016 in GW; source: AGEE-Stat [2018]

This wind farm was built in the record time of seven months [Gramwzielone.pl 2017b]. Also, at the end of 2017 Wikinger wind farm started to operate. It is located about $35 \mathrm{~km}$ from a German island of Rügen in the Baltic Sea. It was built by a Spanish company Iberdrola. The construction cost was approx. 1.4 billion EUR. Wikinger wind farm has the capacity of $350 \mathrm{MW}$ and consists of 70 wind power production plants, whose power is approx. $5 \mathrm{MW}$ each. The wind power production plants cover the area of $34 \mathrm{~km}^{2}$ and were built in 1.5 years [Gramwzielone.pl 2018a]. In the German part of the Baltic there is a wind farm under construction named Arkona. Its power will be $385 \mathrm{MW}$. It will consist of 60 wind power production plants, whose power will be $6 \mathrm{MW}$ each. It is being built within the area of $39 \mathrm{~km}^{2}$ by E.ON, a German energy company and Statoil, a Norwegian fuel company. The entire investment will cost approx. 1.2 billion EUR. The construction will have been completed by the end 2018. Huge wind turbines of the specific output of over $8 \mathrm{MW}$ will become a part of Borkum Riffgrund 2 offshore wind farm, which is being constructed in the German section of the North Sea. Its power will be $450 \mathrm{MW}$ and it will consist of 56 turbines built within the area or $36 \mathrm{~km}^{2}$. The construction is run by Dong Energy, a Danish energy company. V164 wind turbines are to be supplied by MHI-Vestas, a Japanese-Danish consortium. The cost of construction amounts to approx. 1.3 billion EUR. The construction will be completed in the first half of 2019 [Gramwzielone.pl 2018b]. A large offshore wind farm called Merkur of the power of $396 \mathrm{MW}$ is to be built $45 \mathrm{~km}$ away from Borkum Island in the North Sea. It will consist of 66 wind power production plants of the output of $6 \mathrm{MW}$ each, within the area of $39 \mathrm{~km}^{2}$. Merkur Offshore $\mathrm{GmbH}$, a special purpose entity implementing this project has informed about conclusion of negotiations with institutions which will provide its financing. These are, inter alia, Partners Group funds (50\% of shares), UnfraRed Capital Partners (25\% of shares), DEME Group (12.5\% of shares), GE Energy Financial Services (6.25\% of shares) and a French state agency L'Agence de l'environnement et de la maîtrise de l'énergie (ADEME) - 6,25\%. The cost of the entire project amounts to approx. 1.6 billion EUR. The construction

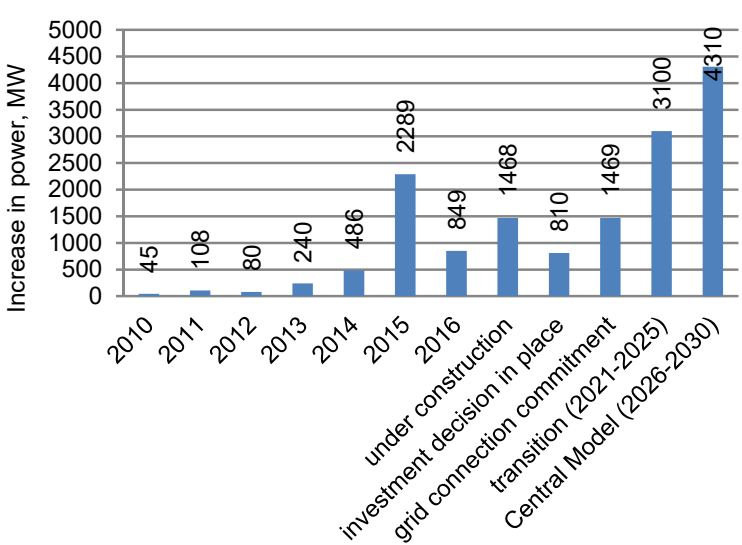

Fig. 6. Increase of offshore wind farm power in Germany in the years 2009-2016, under construction in the years 2017 and 2018 and planned by 2021 in MW;

source: own elaboration based on data of AGEE-Stat [2018], PWC [2018]

completion deadline is March 2019 [BiznesAlert 2018a]. The planned overall increase of offshore wind farms power is to reach approx. 15,039 MW (Fig. 6).

The volume of energy generated by offshore wind farms totalled at approx. $13 \mathrm{TWh}$ in 2016 [PWC 2018]. The German sector of offshore wind power production is characterised with a strong support of the government. The German statutory act about offshore wind energy "Gesetz zur Entwicklung und Förderung der Windenergie auf See" [Gesetz ... 2016] is an element of a broader reform of the law pertaining to renewable energy [Gesetz ... 2000] enacted by the federal parliament in July 2016 and officially issued on 13 October 2016. The act came into force and effect beginning 1 January 2017. It was assumed in the act that the share of energy generated from renewable sources is to be constantly increased. Hence annual growth of gross electric power consumption is expected from the present-day $33 \%$ to $40-45 \%$ by 2025 , $55-60 \%$ by 2035 and no less than $80 \%$ by 2050 .

Pursuant to the United Nations Convention on the Law of the Sea [UN Convention... 1982], the UNCLOS countries can utilize their shoreline of the maximal length of 200 nautical miles within their exclusive economic zones for construction of wind power production plants. In the act about Renewable Sources of Energy 2017 [Gesetz... 2000] amended in 2016 a system of tenders was introduced in order to improve competitiveness and reduce prices of electric power production. Operator of new turbines must compete, bidding the lowest price for a kilowatt hour. The first auction was held in May 2017 (power of 800 MW) and the remaining two in August and November (1,000 MW each). In 2018 and 2019 there are four auctions planned per year of the power of $700 \mathrm{MW}$ each. In 2020 there are three scheduled auctions. The auction system does not apply to offshore wind turbines which will have been put into operation by 1 January 2021, provided that developers have been granted an unconditional confirmation of grid access or connection capacity before January 2017. In the act 
[Gesetz ... 2016] the goal to achieve the power of 15 GW by 2030 was assumed. Reaching this objective was broken down into three stages.

1. The power of $7.7 \mathrm{GW}$ is to be installed within the framework of the existing system on the basis of the connection requirements already granted by the end of 2020.These projects receive the statutory market bonus granted for 20 years plus one year for commissioning. By the end of 2016 the installed power totalled approx. $3.9 \mathrm{GW}$.

2. During the transition period in the years 20212025 connecting to the grid and bonuses will be granted to owners of Project in two auctions in 2017 and 2018. The power of approx. 3.1 GW will be put up for auction then. From 2021 the market bonus will be determined based on tenders.

3 . The fully implemented auction model (central system) will be in force from 2026. The federal government, within the framework of two annual auctions, will be putting up for auction sites which have been pre-approved by the German Federal Maritime and Hydrographic Agency (Ger. Bundesamt für Seeschifffahrt und Hydrographie - BSH) with the power of 700-900 MW per year. BSH in cooperation with Federal Network Agency (Ger. Bundesnetzagentur BNetzA), as an element of such auctions, will provide proper capacity as well as location of converter platforms, location of substations and grid connection cable tracks. New legislature is to result in new projects and adequate grid connections being implemented simultaneously and in the correct chronological order. Construction and operation of underwater connection lines should be based on Section 17d of Energy Management Act [Gesetz... 2005].

A developer wins an auction if they bid the lowest market offer for electric power production. The maximal amount of a subsidy is determined according to the lowest offer value and will be calculated for 20 year after commissioning. The act provided for a 5-year period between a successful auction and commissioning [Gesetz... 2016]. For example, auction completed successfully in 2021 concern projects with the planned date of commissioning in 2026. In order to make a valid bid a developer lodges a security at 200 EUR for the power of $1 \mathrm{~kW}$ they bid for. It must be a bank guarantee or a cash deposit. The guarantee constitutes a security against possible fines which become enforceable should the winning bidder fail to fulfil statutory requirements in the course of a wind farm construction. Statutory periods include a 12-month time limit after winning an auction for submission of planning document as well as an 18-month period from the beginning to the actual accessibility date of a wind farm. After 20 years, the federal authorities can announce another auction of a certain area to be used for wind farms or can reserved a different purpose for the area. In order to obtain operation permit for a wind farm its future operator is obliged to issue a declaration that after elapse of a set wind farm operation all maritime installations can be transported to a prospective next user with no compensation. Developers who have participated in the transition system unsuccessfully will be entitled to enter the market provided the parties winning an auction are eligible and willing to sale these right [PWC 2018]. The aim of this act is to provide coherence between zoning plans, regional planning, installation approval, network financing, transmission lines consolidation and others [GWEC 2016].

\section{CONCLUSIONS}

\section{DENMARK}

1. The power of land and offshore wind farms totalled approx. $5.5 \mathrm{GW}$ as at the end of the year 2016 . Wind energy accounts for $40 \%$ of this country's electric power demand. At present several large offshore wind farms are under construction. It is expected that approx. 1.4 GW of new power will have been installed offshore by the end of 2021.

2. Condition for obtaining a permit for location of wind farms are specified in the Promotion of Renewable Energy Act. A developer must obtain three licenses in order to build a wind farm. Prior to this, they have to win a tender for construction by bidding the lowers price or initiate this process by means of the so-called "open door" procedure.

3. The government supports construction of land and offshore wind farms through subsidies for municipalities which support building of wind farms. It obliges developers to offer to residents of municipalities where they are building wind farms at least $20 \%$ in capital. The government grants a subsidy for energy production at the rate of $25 \mathrm{DKK}$ for $1 \mathrm{kWh}$ above the market price. Should the market price added a subsidy exceed $58 \mathrm{DKK} \cdot \mathrm{kWh}^{-1}$, a subsidy is properly reduced. The government provides building of transmission networks to wind farms under construction. Energinet.dk, a Danish transmission network operator builds and maintains transformer station as well as an underwater cable which transmits electric power on the shore from a near-shore wind farm. Furthermore, it grants loan guarantees for associations, owners of wind farms or other local groups that are building or intend to build wind farms.

\section{GERMANY}

1. The power of land and offshore wind farms totalled approx. 49.6 GW as at the end of the year 2016 . Wind energy production accounts for $15 \%$ of this country's electric power demand. Every year new offshore wind farms are built. In 2016 Germany was the largest EU market of installed new power. It is expected that approx.7.7 GW of new power will have been installed offshore by the end of 2020 .

2. Condition related with location permit for offshore wind farms are specified in Gesetz zur Entwicklung und Förderung der Windenergie auf See Act, 
which is a part of Gesetz für den Vorrang Erneuerbarer Energien Act. The act assumes a steady growth of energy production from renewable sources. It is expected to increase up to $40-45 \%$ by 2025 . From 2017 the act introduced the system of tenders for construction of new offshore wind farms. Developer intending to build them bid the lowest price for 1 kilowatt hour. Moreover, they are required to lodge a security as a project performance guarantee. Each permit for construction of a wind farm includes strict deadlines for completion and adequate penalties for delays.

3. The government supports construction of land and offshore wind farms. It ensures that, within the framework of an auction process, transmission networks are completed in a proper chronological order. In the tender system the government provides subsidies which are calculated for 20 years after commissioning. The law is stable and new regulations are implemented in stages.

When it comes to wind energy, Denmark is a European leader with $40 \%$ of energy demand covered by both onshore and offshore wind farms in 2016, and $44.4 \%$ in 2017 [WindEurope 2018b]. Germany, on the other hand, experienced the highest annual increase from $16 \%$ in 2016 to $20.8 \%$ in 2017 of wind energy in its electricity demand. There is a big number of offshore wind farms under construction. In the more distant future, there is a promising perspective of floating wind farms that will allow reduction of costs connected to foundations construction, energy transport, and will simplify the process of wind farms localisation. A different tool, that can possibly make this process easier in a future, is artificial neural networks which, as proposed by POKONIECZNY [2016], may be used to optimise the onshore wind farms localisation. Possibly the same can be suggested for offshore wind turbines.

\section{REFERENCES}

AGEE-Stat 2018. Zeitreihen zur Entwicklung der erneuerbaren Energien in Deutschland [Time series of renewable energy development in Germany] [online]. [Access 10.03.2018]. Available at: https://www.erneuerbareenergien.de/EE/Redaktion/DE/Downloads/zeitreihenzur-entwicklung-der-erneuerbaren-energien-indeutschland-1990-2017.pdf? blob=publicationFile\&v $=15$ tak

BiznesAlert 2017. W 2030 roku jedna trzecia energii może pochodzić $\mathrm{z}$ wiatru [In 2030 one-third of energy may come from wind] [online]. [Access 28.09.2017]. Available at: http://biznesalert.pl/2030-roku-jedna-trzeciaenergii-moze-pochodzic-wiatru

BiznesAlert 2018a. Niemcy stawiają kolejne morskie farmy wiatrowe [Germany is building another offshore wind farms] [online]. [Access 18.01.2018]. Available at: http://biznesalert.pl/niemcy-stawiaja-kolejne-morskiefarmy-wiatrowe

BiznesAlert 2018b. U wybrzeży Danii powstanie jedna z największych farm wiatrowych na świecie [One of the largest wind farm in the world to be built at the Denmark's coast] [online]. [Access 10.01.2018]. Available at: http://biznesalert.pl/u-wybrzezy-danii-powstaniejedna-najwiekszych-farm-wiatrowych-swiecie.html

BMWi 2015. Offshore wind energy [online]. Bundesministerium für Wirtschaft und Energie. [Access 20.01.2018]. Available at: https://www.erneuerbare-energien.de/ EE/Redaktion/DE/Downloads/offshore-wind-energy.pdf

BWE 2017. A bis Z. Fakten zur Windenergie. Von A wie Arbeitsplätze bis $Z$ wie Ziele der Energieversorgun [A to Z. Facts about wind energy. From A for jobs to Z for goals of energy supply] [online]. Bundesverband WindEnergie pp. 65. [Access 28.09.2017]. Available at: https://www.wind-energie.de/sites/default/files/ download/publication/z-fakten-zur-windenergie/bwe abisz_3-2015_72dpi_final.pdf

Danish Energy Agency 2012. Executive Order no. 68 of 26th January 2012.

Danish Energy Agency 2018. Master data for wind turbines as at the end of December 2017 [online]. [Access 28.09.2017]. Available at: https://ens.dk/en/ourservices/statistics-data-key-figures-and-energy-maps/ overview-energy-sector

DAWID L. 2017a. German support systems for onshore wind farms in the context of Polish acts limiting wind energy development. Journal of Water and Land Development. No. 34 p. 109-115.

DAwID L. 2017b. Chosen problems of wind farms localization in light of new law on investments concerning wind power stations. Infrastructure and Ecology of Rural Areas. No. IV/1/2017 p. 1445-1455.

Directive 2001/77/EC of the European Parliament and of the Council of 27 September 2001 on the promotion of electricity produced from renewable energy sources in the internal electricity market. EU OJ L 283, 27/10/2001.

Directive 2003/30/EC of the European Parliament and of the Council of 8 May 2003 on the promotion of the use of biofuels or other renewable fuels for transport. EU OJ L 123, 17/05/2003.

Directive 2009/28/EC of the European Parliament and of the Council of 23 April 2009 on the promotion of the use of energy from renewable sources and amending and subsequently repealing Directives 2001/77/EC and 2003/30/EC. EU OJ L 140/16, 05/06/2009.

DRUŚ M. 2016. Duński rekord wykorzystania energii z wiatru [Danish record of wind energy use] [online]. Puls Biznesu. [Access 18.01.2018]. Available at: https:// www.pb.pl/rekord-energii-wiatrowej-w-danii-799254

Gesetz für den Vorrang Erneuerbarer Energien (Erneuerbare-Energien-Gesetz - EEG) vom 29. März 2000 [Act of 29 March 2000 on Renewable Energy Sources]. BGB1. I S. 305 with further amendments.

Gesetz über die Elektrizitäts - und Gasversorgung. (Energiewirtschaftsgesetz - EnWG) vom 7. Juli 2005 [Energy Industry Act of 7 July 2005]. BGB1. I S. 1970, 3621 with further amendments.

Gesetz zur Entwicklung und Förderung der Windenergie auf See (Windenergie-auf-See-Gesetz - WindSeeG) vom 13. Oktober 2016 [Offshore Wind Power Act of 13 October 2016]. BGB1. I S. 2258, 2310.

Gramwzielone.pl 2017a. Dania: rusza inwestycja wiatrowa za miliard euro [Denmark: a wind investment for a billion euros starts] [online]. [Access 18.01.2018]. Available at: http://gramwzielone.pl/energia-wiatrowa/28622/ dania-rusza-inwestycja-wiatrowa-za-miliard-euro

Gramwzielone.pl 2017b. Niemcy mają kolejną wielką farmę wiatrowa na morzu [Germany has another large wind farm at sea] [online]. [Access 18.01.2018]. Available at: 
http://gramwzielone.pl/energia-wiatrowa/28304/ niemcy-maja-kolejna-wielka-farme-wiatrowa-na-morzu

Gramwzielone.pl 2017c. Uruchomiono pierwszą ,pływającą" farmę wiatrową [First "floating" wind farm commissioned] [online]. [Access 18.01.2018]. Available at: http://gramwzielone.pl/energia-wiatrowa/28562/ uruchomiono-pierwsza-plywajaca-farme-wiatrowa

Gramwzielone.pl 2018a. Kolejna farma wiatrowa na Bałtyku podłączona do sieci [Another wind farm in the Baltic Sea connected to the grid] [online]. [Access 18.01.2018]. Available at: http://gramwzielone.pl/ energia-wiatrowa/29479/kolejna-farma-wiatrowa-nabaltyku-podlaczona-do-sieci

Gramwzielone.pl 2018b. Największe na świecie turbiny wiatrowe staną u wybrzeży Niemiec [The largest wind turbines in the world to be erected at the German coast] [online]. [Access 18.01.2018]. Available at: http:// gramwzielone.pl/energia-wiatrowa/25924/ najwiekszena-swiecie-turbiny-wiatrowe-stana-u-wybrzezy-niemiec

GWEC 2016. Global wind report 2016. Opening up new markets for business. 8th National renewable energy forum. Ulaanbaatar, Mongolia 5 May 2017 [online]. Brussels. Global Wind Energy Council pp. 76. [Access 10.01.2018]. Available at: http://www. indianwindpower.com/pdf/GWEC_Global_Wind_2016_Report.pdf

MikoŁajczak J., Wróbel B., Jurkowski A. 2009. Możliwości i bariery w produkcji biogazu z biomasy trwałych użytków zielonych w Polsce [Possibilities and limitations in biogas production from permanent grassland biomass in Poland]. Woda-Środowisko-Obszary Wiejskie. T. 9. Z. 2(26) p. 139-155.

OdnawialneFirmy 2018. Elektrownie wiatrowe offshore wady i zalety [Offshore wind power plants - pros and cons] [online]. [Access 18.01.2018]. Available at: https://www.odnawialne-firmy.pl/wiadomosci/pokaz/ 18,elektrownie-wiatrowe-offshore-wady-i-zalety

POKONIECZNY K. 2016. Using artificial neural networks to determine the location of wind farms. Miedzna district case study. Journal of Water and Land Development. No. 30 p. 101-111.

Promotion of renewable energy act No. 1392 of 27 December 2008 [online]. [Access 15.01.2018]. Available at: https://www.ecolex.org/details/legislation/ act-on-thepromotion-of-renewable-energy-no-1392-of-2008-lexfaoc099079/
PSEW 2016. Stan energetyki wiatrowej w Polsce w 2015 roku [Wind energy in Poland in 2015]. Warszawa. Polskie Stowarzyszenie Energetyki Wiatrowej pp. 74.

PWC 2018. Unlocking Europe's offshore wind potential, PWC. Moving towards a subsidy free industry [online]. Amsterdam. PricewaterhouseCoopers B.V. pp. 44. [Access 20.05.2018]. Available at: https://www. pwc.nl/nl/assets/documents/pwc-unlocking-europesoffshore-wind-potential.pdf

StryjeCKi M., MielniczuK M., Biegaj J. 2011. Przewodnik po procedurach lokalizacyjnych i środowiskowych dla farm wiatrowych na polskich obszarach morskich [A guidebook to location and environmental procedures for wind farms in Poland's maritime areas]. Warszawa. Fundacja na rzecz Energetyki Zrównoważonej. ISBN 987-83-934100-0-2 pp. 156.

TRANCIK J.E. 2014. Back the renewables boom. Nature. No. 507 p. $300-302$.

United Nations Convention on the Law of the Sea 1982 [online]. [Access 25.01.2018]. Available at: http://www. un.org/depts/los/convention_agreements/texts/unclos/ unclos_e.pdf

WindEurope 2017. The European offshore. Wind Europe Key trends and statistics 2016 [online]. [Access 02.05.2018]. Available at: https://windeurope.org/wpcontent/uploads/files/about-wind/statistics/WindEuropeAnnual-Offshore-Statistics-2016.pdf

WindEurope 2018a. Offshore wind in Europe. Wind Europe. Key trends and statistics 2017 [online]. [Access 20.01.2018]. Available at: https://windeurope. org/wpcontent/uploads/files/about-wind/statistics/WindEuropeAnnual-Offshore-Statistics-2017.pdf

WindEurope 2018b. Wind in power 2017. Annual combined onshore and offshore wind energy statistics [online]. [Access 02.05.2018]. Available at: https://windeurope. org/wp-content/uploads/files/about-wind/statistics/ WindEurope-Annual-Statistics-2017.pdf

4C Offshore 2018a. Kriegers Flak. [Access 10.01.2018]. Available at: http://www.4coffshore.com/windfarms/ kriegers-flak-denmark-dk37.html

4C Offshore 2018b. Vesterhav. [Access 10.01.2018]. Available at: http://www.4coffshore.com/windfarms/ vesterhav-nord-syd-denmark-dk48.html

\section{Leszek DAWID}

\section{Perspektywy rozwoju morskich farm wiatrowych w wybranych krajach Unii Europejskiej}

\section{STRESZCZENIE}

Na koniec 2016 r. w budowie były 84 farmy wiatrowe w 11 krajach europejskich. Inwestycje w tym sektorze są ogromne. Średni koszt budowy farmy wiatrowej wynosi około 4 mln euro na $1 \mathrm{MW}$ zainstalowanej mocy. Morska energetyka wiatrowa odgrywa także znaczącą rolę w procesie zapewnienia Europie bezpieczeństwa energetycznego oraz redukcji gazów cieplarnianych. W artykule przedstawiono perspektywy rozwoju morskich farm wiatrowych w wiodących pod tym względem krajach UE. W niniejszym artykule badaniom poddano morskie farmy wiatrowe w Niemczech i Danii. Badania przeprowadzono głównie na podstawie analizy aktów prawnych, literatury przedmiotu, stron internetowych. W artykule analizowano moc farm wiatrowych, systemy wsparcia oraz kryteria związane z lokalizacją farm wiatrowych na morzu. Niemiecki i duński sektor morskiej energetyki wiatrowej charakteryzuje się silnym wsparciem rządu. W obu krajach dąży się do corocznego zwiększania udziału produkcji energii wiatrowej.

Słowa kluczowe: energia wiatrowa, morskie farmy wiatrowe, odnawialne źródła energii, systemy wsparcia 